Annals of Plant and Soil Research 23(1): 48-53 (2021)

https://doi.org/10.47815/apsr.2021.10028

\title{
Sustainable agricultural practices for improving growth, yield and quality of turmeric (Curcumalonga L.)
}

\author{
R.R. LOHAR ${ }^{1}$ AND C.P. HASE ${ }^{2}$ \\ Department of Environmental Science, B.G. College, Sangvi, Pune,(RIT, Rajaramnagar, Sangli), Maharashtra, \\ India-411027
}

Received: November, 2020; Revised accepted: January, 2021

\begin{abstract}
A field experiment was carried out in district-Sangli (Maharashtra) to study the effect of sustainable agricultural practices for improving growth, yield and quality of turmeric (Curcuma longa L.) variety Salem during 2018 and 2019. Twelve treatments were evaluated in randomized block design with three replications. The results revealed that plant height, leaves/plant, width of leaves, leaf area index and clumps/plant tended to increase with age of plant and maximum values were recorded at $150 \mathrm{DAP}$, irrespective to various treatments. Application of $50 \% \mathrm{RDF}+50 \% \mathrm{NC}$ resulted in significantly higher fresh weight of primary rhizome $(46.5 \mathrm{~g})$, fresh weight of secondary rhizome $(55.5 \mathrm{~g})$ and high marketable yield of rhizome $\left(251.2 \mathrm{q} \mathrm{ha}^{-1}\right)$ over control. The total yield of fresh rhizome per plot was comparatively on higher side $(418.5 \mathrm{~g})$ when compared to control $(308.1 \mathrm{~g})$ and other treatments. The application of $50 \%$ RDF $+50 \%$ NC proved superior for enhancing the quality parameters of turmeric such as fats $(1.06 \%)$, protein $(1.25 \%)$, carbohydrates $(9.25 \%)$ and curcumin $(5.13 \%)$ content to other treatments. Soil productivity was recorded maximum due to combined application of $50 \%$ RDF $+50 \%$ NC than the application of all these fertilizers alone. Fertility status of post-harvest soil improved with most of the treatments over control and higher values were recorded with $50 \%$ RDF $+50 \%$ NC treatment.
\end{abstract}

Keywords: Inorganicfertilizer, organic manures, bio fertilizers, growth, yield, quality, turmeric

\section{INTRODUCTION}

Turmeric (Curcumalonga L.) is one of the most important traditionalspice crop, which is utilized for various dishes and for the preparation of different cosmetics and medicine in India.It has been recognized as a pharmaceutical drug due to the curcumin and essential oil contents. Turmeric is exported to over 129 countries. In the year 2019-20, India has exported turmeric worth of 117.74 USD million (Anonymous, 2020). The uses of chemical fertilizers badly affect the soil fertility and environmental quality (Kamal and Yousuf, 2012). Organic manures and bioferilizers are the best ecofriendly alternative to chemical fertilizers. They have become popular among turmeric growing farmers as they improve yieldand quality (Kadam and Kamble, 2020). Organic fertilizers improve the soil health and limit ecological contamination reducing the cost of input on chemical fertilizers. Use of biofertilizers fertilizers quickly improve soil microbial biomass and their development (Dinesh et al., 2010). Soil microorganisms develop soil richness (Yamwaski et al., 2013). Use of biofertilizers like Azospirillium is useful for reducing the use of synthetic nitrogenous fertilizers and improves soil fertility. Use of PSB is effective to solubilize fixed phosphorus in the soil.The blend of organic manures and biofertilizers is suitable for improving the yield of turmeric in a sustainable manner (Sreekala, 2015). Utilization of various combinations of organic manures like FYM, Vermicompost and Neem cake greatly influence growth, yield and quality of turmeric (Sharma et al., 2015). The combined applications of biofertilizers and organic manures along with chemicalfertilizers play key role in turmeric cultivation (Kadamand Kamble, 2020). With this consideration in mind the present investigation was conducted to study the sustainable agricultural practices through the application of organic manures and biofertilizers for improving growth, yield, curucumin content and soil fertility.

\footnotetext{
${ }^{1}$ Corresponding author email: rajaram.lohar@ritindia.edu

${ }^{2}$ Department of Botany, B. G. College Sangvi, Pune
} 


\section{MATERIALS AND METHODS}

The present investigation was carried out at Ashta (Sangli).The latitude and longitude coordinators of study site are $16.86^{\circ} \mathrm{N}$ and $74.57^{\circ} \mathrm{E}$ respectively. The average temperature of experimental site is $25.4^{\circ} \mathrm{C}$ and total annual rainfall is $580 \mathrm{~mm}$. The experimentwas conducted on black cotton soil having $\mathrm{pH} 7.8$, organic carbon $4.0 \mathrm{~g} \mathrm{~kg}^{-1}$, available $\mathrm{N} 140.2 \mathrm{~kg}$ $\mathrm{ha}^{-1}, \mathrm{P} 16.6 \mathrm{~kg} \mathrm{ha}^{-1}$ andK $131.2 \mathrm{~kg} \mathrm{ha}^{-1}$. The experiment was carried out in randomized block design with three replications. The rhizomes were planted at $70 \mathrm{~cm}$ and $30 \mathrm{~cm}$ spacing in the field using raised beds of size $3.5 \times 2.5 \mathrm{~m}$ having $15 \mathrm{~cm}$ height.Turmeric rhizomes of variety Salem were planted during the first week of April, 2018 and 2019. The rhizomes were covered with soil properly and watering was done immediately. Treatments were T1:100\% RDF (120:60:40), T2:Farmyard manure 15tha ${ }^{-1}$, T3:Vermicompost 5tha ${ }^{-1}$, T4:Neem Cake 5tha ${ }^{-1}$, T5:Azospirrilium-5 $\mathrm{Kgha}^{-1}$, T6:PSB 5 $\mathrm{Kgha}^{-1}$, T7:50\% RDF + 50\% FYM, T8:50\% RDF + 50\% VC, T9:50\% RDF + 50\% NC, T10:50\% RDF + Azospirillium 5kg/ha, T11:50\% RDF + PSB $5 \mathrm{~kg} / \mathrm{ha}$, T12:Control(No any application of fertilizer).The organic inputs namely FYM, VC and Neem cake were applied basally during final land preparation @ 15t, 5t, 5t ha ${ }^{-1}$, respectively. Azospirillium was applied to the rhizome @ 5g $\mathrm{kg}^{-1}$ and PSB was directly applied through soil. Urea, single superphosphate and muriate of potash were used as inorganic source of $N, P$ and $\mathrm{K}$, respectively. The crop was irrigated after 15 to 20 days interval by using micro irrigation. Time to time inter cultivation and weedingwas done regularly up to harvest.The observations were recorded on growth parameters such as plant height, number of leaves per plant, width of leaves, number of clumps per plant were recorded at 90,120 and 150 DAP.Leaf area index (LAI) was calculated at 120 and 150 DAP using standard methods by selecting ten plants per treatment randomly. Yield parameters such as weight of primary rhizome, weight of secondary rhizome, fresh rhizomeand rhizome yield per plot were recorded at harvest. The crop was harvested after eight months in the month of Januaryat full maturity of rhizome. The harvested rhizomes were digged out manually and cleaned properly.Moisture content, protein and total fat were determined by AOAC (2006) method. Total carbohydrate was determined by difference, which is calculated by subtracting the measured protein, fat, ash and moisture from 100, phenol sulphuric method as given by AOAC (2006). Ash content was determined by drying the sample in oven at $100^{\circ} \mathrm{C}$ and then it was ashed in muffle furnace at $550^{\circ} \mathrm{C}$ for $5 \mathrm{hrs}$ (AOAC 2006). Curcumin content of fresh rhizome was determined as per the method given by FSSAI (2016).Soil samples collected from experimental plots wereanalyzed for available nitrogen by alkaline potassium permanganate method (Subbiah and Asija, 1956), phosphorus by the method of Brays and Kurtz (1945), potassium by flame photometer. The organic carbon was determined by Walkley-Black chromic acid wet oxidation method.The economics of turmeric productionwas calculated depending on input cost and market price.The data were statistically analyzed for least significance difference (LSD) at $5 \%$ probability level and coefficient of correlations by analysis of variance (ANOVA) using data analysis tool pack of MS Excel (2013).

\section{RESULTS AND DISCUSSIONS}

\section{Growth Parameters}

It was observed that the plant height, number of leaves, width of leaves and leaf area index (LAI)were increased with theapplication of organic manures and biofertilizers than the inorganic fertilizers and control (Table 1). Among the treatment of organic manures and biofertilizers, maximum plant height $(43.7,77.3$ and $79.8 \mathrm{~cm}$ ), number of leaves $(8.7,22.8$ and $27.8)$, width of leaves $(8.0,8.9$ and $10.1 \mathrm{~cm})$ were recorded by neem cake $\left(T_{4}\right)$ alone at 90,120 and 150 DAP along with the increased leaf area index (0.94 and 1.48) at 120 and 150 DAP. The increase in number of clumps (4.03, 4.9 and 6.1) was recorded with neem cake $\left(T_{4}\right)$. The increases in growth characters may be attributed to increased availability of nutrients in soil.The maximum plant height (54.6, 105.2 and 108.2 $\mathrm{cm})$, number of leaves (10.6, 25.6 and 30.6), width of leaves (8.9, 9.2 and 10.8) and LAI (1.31 and 1.66) at 120 and 150 DAP and number of clumps (4.6, 5.4 and 6.4) were observed with $50 \%$ RDF $+50 \%$ neem cake followed by the $\mathrm{T}_{4}$, $\mathrm{T}_{10}$ and $\mathrm{T}_{11}$ treatments as compared with inorganic fertilizers and control. The beneficial effect of organic manureson growth characters might be due to additional supply of nutrients as well as improvement in physic-chemical properties of soil. These findings are in good agreement with those of Kumar et al., (2018). 
Table: 1.Effect ofdifferent treatments on growth characters of turmeric (pooled for two years)

\begin{tabular}{|c|c|c|c|c|c|c|c|c|c|c|c|}
\hline \multirow{3}{*}{ Treatments } & \multirow{2}{*}{\multicolumn{3}{|c|}{$\frac{\text { Plant height }(\mathrm{cm})}{\text { DAP }}$}} & \multirow{2}{*}{\multicolumn{3}{|c|}{$\frac{\text { Leaves per plant }}{\text { DAP }}$}} & \multirow{2}{*}{\multicolumn{3}{|c|}{$\frac{\text { Width of leaves }(\mathrm{cm})}{\text { DAP }}$}} & \multirow{2}{*}{\multicolumn{2}{|c|}{$\frac{\text { LAI }}{\text { DAP }}$}} \\
\hline & & & & & & & & & & & \\
\hline & 90 & 120 & 150 & 90 & 120 & 150 & 90 & 120 & 150 & 120 & 150 \\
\hline$T_{1}$ & 41.0 & 74.0 & 74.0 & 7.6 & 24.8 & 25.8 & 7.1 & 8.0 & 9.8 & 0.81 & 1.37 \\
\hline $\mathrm{T}_{2}$ & 42.1 & 75.6 & 75.6 & 8.1 & 25.9 & 26.3 & 7.2 & 8.1 & 9.9 & 0.83 & 1.40 \\
\hline $\mathrm{T}_{3}$ & 43.3 & 76.1 & 76.1 & 8.6 & 26.0 & 27.1 & 7.6 & 8.3 & 10.1 & 0.86 & 1.44 \\
\hline $\mathrm{T}_{4}$ & 43.7 & 77.3 & 79.8 & 8.7 & 22.8 & 27.8 & 8.0 & 8.9 & 10.1 & 0.94 & 1.48 \\
\hline $\mathrm{T}_{5}$ & 40.9 & 74.9 & 74.9 & 6.9 & 22.4 & 27.1 & 7.8 & 9.0 & 10.2 & 0.92 & 1.38 \\
\hline$T_{6}$ & 41.2 & 74.8 & 74.8 & 6.8 & 21.5 & 26.3 & 7.9 & 9.1 & 10.3 & 0.93 & 1.41 \\
\hline $\mathrm{T}_{7}$ & 45.1 & 100.4 & 100.4 & 8.9 & 25.5 & 27.9 & 8.0 & 9.1 & 10.4 & 1.2 & 1.52 \\
\hline $\mathrm{T}_{8}$ & 49.6 & 104.3 & 104.3 & 9.2 & 26.4 & 28.4 & 8.8 & 9.1 & 10.7 & 1.3 & 1.60 \\
\hline $\mathrm{T}_{9}$ & 54.6 & 105.2 & 108.2 & 10.6 & 25.6 & 30.6 & 8.9 & 9.2 & 10.8 & 1.316 & 1.66 \\
\hline $\mathrm{T}_{10}$ & 41.4 & 75.2 & 75.2 & 7.9 & 23.5 & 28.8 & 7.8 & 8.8 & 10.0 & 0.90 & 1.40 \\
\hline $\mathrm{T}_{11}$ & 42.0 & 76.0 & 76.0 & 8.0 & 24.5 & 26.5 & 7.9 & 8.9 & 10.1 & 0.92 & 1.41 \\
\hline $\mathrm{T}_{12}$ & 37.8 & 72.4 & 72.4 & 5.8 & 22.0 & 23.9 & 6.7 & 7.0 & 8.0 & 0.79 & 1.06 \\
\hline $\mathrm{SE}_{ \pm}$ & 1.30 & 3.93 & 1.19 & 0.32 & 0.50 & 0.41 & 0.17 & 0.12 & 0.09 & 0.05 & 0.028 \\
\hline LSD & 9.6 & 29.1 & 8.8 & 2.3 & 3.7 & 3.1 & 1.2 & 0.9 & 0.6 & 0.42 & 0.21 \\
\hline CV \% & 9.7 & 15.7 & 3.7 & 12.7 & 6.8 & 5.0 & 7.1 & 4.8 & 2.9 & 19.0 & 6.4 \\
\hline
\end{tabular}

\section{Yield attributes and yield}

The maximum values of primary rhizome $(46.5 \mathrm{~g})$, secondary rhizome $(55.5 \mathrm{~g})$, fresh wt. of rhizome $(418.5 \mathrm{~g})$ and Rhizome yield per plot $\left(19.9 \mathrm{~kg} / \mathrm{m}^{2}, 251.2 \mathrm{qha}^{-1}\right)$ were recorded with 50 $\%$ RDF $+50 \%$ NC followed by treatments T10 and T11. The increase in yield due to $50 \%$ RDF + $50 \%$ NC was $25 \%$ over control which may be attributed to increased availability of nutrients in soil as a result of inorganic fertilizer and organic manure addition (Roy and Hore, 2011). These findings are in accordance with the results reported by Kamal and Yousuf (2012), Kumar et al., (2018) and Singh et al., (2015) who reported that the application of FYM, vermicompost, along with the inorganic fertilizer had positiveimpact on growth, yield parameters and quality of turmeric. Among the different treatments, the positive influence of combined applications of organic manures and biofertilizers was observed for the growth, yield and quality of turmeric over inorganic fertilizer alone and control. The minimum values of yield attributes were recorded under control owing to poor soil fertility.

Table 2: Effect of different fertilizer treatments onyield attributes of turmeric (pooled for two years)

\begin{tabular}{|c|c|c|c|c|c|c|c|c|}
\hline \multirow{2}{*}{ Treatments } & \multicolumn{3}{|c|}{ Clumps/plant } & $\begin{array}{c}\text { Primary } \\
\text { Rhizome }\end{array}$ & $\begin{array}{c}\text { Secondary } \\
\text { Rhizome }(\mathrm{g})\end{array}$ & $\begin{array}{c}\text { Fresh weight of } \\
\text { rhizomes/Plant } \\
(\mathrm{g})\end{array}$ & $\begin{array}{c}\text { Rhizome } \\
\text { yield } \\
\left(\mathrm{kg} / \mathrm{m}^{2}\right)\end{array}$ & $\begin{array}{c}\text { Rhizome } \\
\text { yield } \\
\left(\mathrm{qha}^{-1}\right)\end{array}$ \\
\hline $\mathrm{T}_{1}$ & 4.1 & 5.0 & 5.3 & 40.7 & 45.5 & 378.3 & 15.9 & 201.0 \\
$\mathrm{~T}_{2}$ & 4.2 & 5.1 & 5.4 & 40.9 & 46.8 & 371.5 & 17.6 & 221.5 \\
$\mathrm{~T}_{3}$ & 3.9 & 4.9 & 6.0 & 43.2 & 48.9 & 382.2 & 17.8 & 224.7 \\
$\mathrm{~T}_{4}$ & 4.1 & 5.1 & 6.2 & 43.2 & 53.8 & 398.2 & 18.6 & 234.2 \\
$\mathrm{~T}_{5}$ & 4.0 & 5.0 & 6.1 & 42.1 & 44.8 & 391.0 & 17.9 & 225.1 \\
$\mathrm{~T}_{6}$ & 4.1 & 4.9 & 6.2 & 43.0 & 48.9 & 390.1 & 18.0 & 226.9 \\
$\mathrm{~T}_{7}$ & 4.2 & 5.2 & 6.3 & 41.9 & 43.9 & 403.0 & 19.4 & 244.6 \\
$\mathrm{~T}_{8}$ & 4.5 & 5.3 & 6.4 & 44.6 & 55.2 & 408.5 & 19.6 & 247.1 \\
$\mathrm{~T}_{9}$ & 4.6 & 5.4 & 6.4 & 46.5 & 55.5 & 418.5 & 19.9 & 251.2 \\
$\mathrm{~T}_{10}$ & 3.9 & 4.9 & 6.1 & 42.1 & 44.9 & 397.0 & 18.6 & 234.1 \\
$\mathrm{~T}_{11}$ & 4.0 & 5.0 & 6.1 & 43.2 & 49.0 & 400.0 & 18.6 & 234.8 \\
$\mathrm{~T}_{12}$ & 3.8 & 4.2 & 4.9 & 36.4 & 42.3 & 308.1 & 13.5 & 170.0 \\
$\mathrm{SE}$ & 0.06 & 0.05 & 0.1 & 0.49 & 1.28 & 3.32 & 0.50 & 6.40 \\
$\mathrm{LSD}_{ \pm}$ & 0.47 & 0.39 & 0.8 & 3.6 & 9.5 & 24.6 & 3.6 & 49.4 \\
$\mathrm{CV}_{\%}$ & 5.0 & 3.4 & 6.1 & 3.8 & 8.7 & 2.7 & 9.7 & 9.7 \\
\hline
\end{tabular}




\section{Quality Parameters}

The curcumin content was increased due to organic manures and biofertilizers than those of inorganic fertilizers alone and control (Table $3)$. The higher curcumin content $(4.81 \%)$ was recorded in treatment having neem cake as compared to other organic manure, inorganic fertilizer and control. Kumar et al. (2018) reported that curcumin content was enhanced by the combination of organic manures + inorganic fertilizer + biofertilizers. The highest curcumin content $(5.13 \%)$ was recordedwith application of $50 \%$ RDF + 50\%neem cake followedby $50 \%$ RDF + PSB (4.97 \%) indicating that theintegrated use of organic manures and biofertilizers had significant effect on curucumin content in the rhizome. Similar results were also reported by Singh et al., (2015).The integrated use of inorganic fertilizer, organic manure and biofertilizer significantly improvedthe biochemical constituents of rhizome over control and other alone treatments (Table 3). The application of $50 \%$ RDF $+50 \%$ neem cake emerged as the most superior treatment over control and other treatments. The significant increase in fats $(1.06 \%)$, protein $(1.25 \%)$ and carbohydrate $(9.25 \%)$ was recorded with $\mathrm{T}_{9}$ treatment. It may be used as potentially attractive source of protein, carbohydrates and curcumin. The results of the study support the development of sustainable agricultural practices for turmeric cultivation (Jain and Parihar, 2017, Mane et al, 2018).

Table 3:Effect of different treatments on biochemical composition of fresh turmeric rhizomes (Pooled for two years)

\begin{tabular}{c|c|c|c|c|}
\hline Treatments & Total fat (\%) & Carbohydrates (\%) & Proteins (\%) & Curcumin (\%) \\
\hline $\mathrm{T}_{1}$ & 0.77 & 6.68 & 0.89 & 4.61 \\
$\mathrm{~T}_{2}$ & 0.81 & 8.11 & 0.92 & 4.64 \\
$\mathrm{~T}_{3}$ & 0.84 & 8.18 & 0.91 & 4.78 \\
$\mathrm{~T}_{4}$ & 0.82 & 8.15 & 0.94 & 4.81 \\
$\mathrm{~T}_{5}$ & 0.71 & 6.78 & 0.88 & 4.87 \\
$\mathrm{~T}_{6}$ & 0.78 & 6.98 & 0.92 & 4.88 \\
$\mathrm{~T}_{7}$ & 0.98 & 8.97 & 1.01 & 4.91 \\
$\mathrm{~T}_{8}$ & 1.03 & 9.12 & 1.21 & 5.11 \\
$\mathrm{~T}_{9}$ & $\mathbf{1 . 0 6}$ & $\mathbf{9 . 2 5}$ & 1.25 & $\mathbf{5 . 1 3}$ \\
$\mathrm{T}_{10}$ & 0.99 & 7.95 & 1.01 & 4.95 \\
$\mathrm{~T}_{11}$ & 1.01 & 8.01 & 1.05 & 4.17 \\
$\mathrm{~T}_{12}$ & 0.82 & 6.54 & 0.79 & 3.98 \\
\hline
\end{tabular}

\section{Soil fertility}

Available nitrogen, phosphorus, potassiumand organic carbon status of the post harvest soil increased significantly with the application of organic manures and biofertilizers alone (Table 4). The values of nitrogen, phosphorus, potassium and organic carbon contents also increased with integrated use of inorganic fertilizer with organic and biofertilzer treatments $\left(T_{7}, T_{8}, T_{9}, T_{10}\right.$ and $\left.T_{11}\right)$. The highest values of these parameters were recorded with application of $50 \%$ RDF $+50 \%$ neem cake in post harvest soil.Similar trend was reported by Sanwal (2007) who noted that application of organic manureshad positive impact on fertility of soil.Application of organic manures like FYM, vermicompost and biofertilizers like Azospirillium, PSB improved soil fertility and yield of turmeric
(Dinesh et al., 2010). The minimum values of organic carbon, available nitrogen, phosphorus and potassium were recorded under control.

\section{Economics}

It was revealed from the data (Table 4) that a significant increase in rhizome yield $(251.2$ $\mathrm{q} \mathrm{ha}^{-1}$ ) was obtained with turmeric variety Salem under the treatment of $50 \%$ RDF $+50 \%$ neem cake with maximum net return of Rs. 11, 34,258 $\mathrm{ha}^{-1}$ and cost benefit ratio 1: 4.04 followed by $50 \%$ RDF $+50 \%$ Vermicompost which gave the net return of Rs. 11, 09479.00 ha $^{-1}$ and cost benefit ratio 1: 3.97. These results are in conformity with several researchers (Nanda et al., 2012, Kadamand Kamble, 2020). The lower values of net return and C: B ratios were recorded under control. 
Table 4: Effect of different fertilizer treatments on available nutrients and organic carbon $\left(\mathrm{g} \mathrm{kg}^{-1}\right)$ in post harvest soil and economics (Pooled over 2 years)

\begin{tabular}{|c|c|c|c|c|c|c|c|}
\hline Treatments & $\begin{array}{c}\mathrm{N} \\
\left(\mathrm{kg} \mathrm{ha}^{-1}\right)\end{array}$ & $\begin{array}{c}\mathrm{P}_{2} \mathrm{O}_{5} \\
\left(\mathrm{~kg} \mathrm{ha}^{-1}\right)\end{array}$ & $\begin{array}{c}\mathrm{K}_{2} \mathrm{O} \\
\left(\mathrm{kg} \mathrm{ha}^{-1}\right)\end{array}$ & $\begin{array}{c}\mathrm{OC} \\
\left(\mathrm{g} \mathrm{kg}^{-1}\right)\end{array}$ & $\begin{array}{c}\text { Gross incomes } \\
\left(\mathrm{Rs} \mathrm{ha}^{-1}\right)^{*}\end{array}$ & $\begin{array}{c}\text { Net income } \\
\left(\mathrm{Rs} \mathrm{ha}^{-1}\right)\end{array}$ & $\begin{array}{c}\mathrm{C}: \mathrm{B} \\
\text { Ratio }\end{array}$ \\
\hline $\mathrm{T}_{1}$ & 189.3 & 17.8 & 164.3 & 4.00 & 1206480 & 805325.4 & $1: 3.00$ \\
$\mathrm{~T}_{2}$ & 197.6 & 21.3 & 180.2 & 4.28 & 1329120 & 912662.4 & $1: 3.19$ \\
$\mathrm{~T}_{3}$ & 213.4 & 21.8 & 183.0 & 4.23 & 1348680 & 927217.5 & $1: 3.20$ \\
$\mathrm{~T}_{4}$ & 220.7 & 25.7 & 185.1 & 4.68 & 1405500 & 979165 & $1: 3.29$ \\
$\mathrm{~T}_{5}$ & 231.3 & 22.1 & 183.7 & 5.12 & 1351140 & 982954.4 & $1: 3.66$ \\
$\mathrm{~T}_{6}$ & 235.1 & 21.3 & 184.1 & 5.20 & 1361580 & 986010.9 & $1: 3.62$ \\
$\mathrm{~T}_{7}$ & 258.9 & 24.3 & 189.5 & 5.33 & 1467720 & 1064097 & $1: 3.63$ \\
$\mathrm{~T}_{8}$ & 268.7 & 24.5 & 191.3 & 5.46 & 1482600 & 1109479 & $1: 3.97$ \\
$\mathrm{~T}_{9}$ & 272.4 & 26.7 & 192.0 & 5.51 & 1507320 & 1134258 & $1: 4.04$ \\
$\mathrm{~T}_{10}$ & 248.3 & 21.3 & 154.1 & 5.24 & 1405140 & 1014043 & $1: 3.59$ \\
$\mathrm{~T}_{11}$ & 243.2 & 12.6 & 156.1 & 5.27 & 1408920 & 1014422 & $1: 3.57$ \\
$\mathrm{~T}_{12}$ & 146.2 & 16.6 & 132.2 & 3.80 & 1020540 & 678659.1 & $1: 2.98$ \\
\hline
\end{tabular}

${ }^{*}$ Average market rate of turmeric rhizome Rs. 6000/q,

${ }^{* *}$ Total expenditure cost includes the expenditure from land preparation to harvesting of turmeric

It may be concluded from the results that, turmeric variety Salem showed promising results with the application of inorganic +neem cake and inorganic fertilizer with biofertilizer. There was significant improvement with these treatments in growth, yield attributes and quality of turmeric with respect to biochemical constituents and curcumin content. The integrated use of

\section{REFERENCES}

Anonymous (2020) Major State wise Area and production of Spices in India, Retrieved June, 2020 from http:// www.indianspices.com/statistics, www.connect2india.com

AOAC (2006) Official methods of analysis.Association of Official Analytical Chemists International. In: Horwitz, W. (Ed), $18^{\text {th }} \mathrm{Ed}$. AOAC press. Arlington, VA, USA,

Dinesh, R., Srinivasan, V., Hamza, S. and Manjusha, A. (2010) Short term incorporation of organic manures and biofetilizers influences biochemical and microbial characteristics of soil under an annual crop (Curcuma longa L.). Bioresource Technology. 101: 46974702.

FSSAI (2016) Food Safety and Standards Authority of India, Manual of Methods of Analysis of Foods: Spices and Condiments, pp, 34-35. inorganic fertilizer + neem cake + biofertilizer was found to be highly effective to improve the soil fertility. The cost benefit ratio obtained with these treatments was comparatively higher indicating that such treatments can be recommended to the farmers for the sustainable cultivation practice for higher production of turmeric crop.

Jain, A., Parihar, D. K., (2017) Nutritional value of curicuma species collected from Different Agro Climatic Regions of Chhattisgarh. American Journal of Ethno medicine. 4:(2)::20.

Kadam, J.H. and Kamble, B. M. (2020) Effect of organic manures on growth, yield and quality of turmeric (Curcumin longa L). Journal of Applied and Natural Science 12(2):91-97.

Kamal, M.Z.U. and Yousuf, M.N. (2012) Effect of organic manures on growth, rhizome yield and quality attributes of turmeric (Curcuma longa L.). The Agriculturist 10 (1):16-22.

Kumar, A.,Tewari, S., Singh, I., Pandey, R., Kumar, D., and Anand, R.(2018)Effect of nutrient sources on growth, yield and quality of turmeric under harad (Terminaliachebula) based agroforestry system. Indian Journal of Agroforestry 20:2: 1-6. 
Mane, R. P.,Kshirsagar, R. B., Sawate, A. R., Patil, B. M. and Kale, R. G., (2018) Studies on evaluation of physicochemical and nutritional properties of fresh turmeric rhizome.Journal of Pharmacognosy and Phytochemistry 7 (2): 2895-2897.

Nanda, S. S., Mohapatra, S. and Mukshi, S. K., (2012) Integrated effect of organic and inorganic sources of nutrients on turmeric (Curcuma longa).Indian Journal of Agronomy 57(2):191-194.

Roy, S. S. and Hore, J. K. (2011) Effect of organic manures and biofertilizers on growth, yield and quality of turmeric intercropped in arecanut garden.Journal of Plantation Crops 39(3): 00-00

Sanwal, S. K., Laxminarayana, K.; Yadav, R. K.; Rai, N.; Yadav, D.S. and MousumiBhuyan (2007) Effect of organic manures on soil fertility, growth, physiology, yield and quality of turmeric. Indian Journal of Horticulture 64 (4): 444 $-449$.
Sharma, I., Phukon, M., and Borgohain, R. (2015) Effect of organic manure, vermicomposting and neem cake on growth, yield and profitability of turmeric (Curcuma longa L.)Variety-Megha Turmeric-1.Asian Journal of Biological Sciences 10(2): 133-137.

Singh, R.P., Jain P.K., Verma, A. and Jhade, R.K. (2015) Yield and quality parameters of turmeric as influenced by application of bio-fertilizers and organic manures. Environmental and Ecology 33(1): 50-54.

Sreekala, G.S. (2015) Effect of organic manures and biofertilizers on nutrient status of soil in ginger intercropped in coconut garden. International Journal of Current Research 7(3): 13694-13698.

Yamawaki, K., Matsumura, A., Hattori, R., Tarui, A., Hossain, M.A., Ohashi, Y. and Daimon, H. (2013) Effect of inoculation with arbuscular mycorrhizal fungi on growth, nutrient uptake and curcumin production of turmeric (Curcuma longa L.). Agricultural Science 4(2): 6-71. 